\title{
Exploring the feasibility of setting up community allotments on abandoned agricultural land: A place, people, policy approach
}

\author{
Jean Marc Pace Ricci, Elisabeth Conrad ${ }^{*}$ \\ Institute of Earth Systems, University of Malta, Malta
}

\section{A R T I C L E IN F O}

\section{Keywords:}

Agricultural abandonment

Allotments

Peri-urban areas

Feasibility

Malta

Urban agriculture

\begin{abstract}
A B S T R A C T
Agricultural land abandonment is a key driver of land use change in Europe. At the same time, urban land cover is expanding rapidly, often resulting in increasingly limited public access to green spaces. Within this context, this exploratory study sought to explore the feasibility of siting community allotment gardens on abandoned agricultural land within the small island state of Malta. Such an initiative could serve a dual purpose, i.e., limiting degradation of abandoned land on the one hand, and providing increased opportunities for community interaction with nature, on the other. Feasibility was explored in three steps, focusing on place, people, and policy, respectively. First, land within the peri-urban regions of three municipalities was identified and evaluated for suitability on the basis of specific criteria adapted for the local context. Second, interviews were employed to explore the views of members of the public and of other relevant stakeholders, and to identify potential coali tions of support. Finally, existing legal and policy frameworks for land-use planning were evaluated to determine the extent to which they are able to accommodate such land repurposing. Results showed that suitable land is available within all three municipalities considered. Furthermore, there is clear public support for the establishment of such allotments, as well as moderate interest by respondents in participating actively through rental of plots. However, institutional barriers in the policy sphere would need to be addressed. Key recommendations include the creation of a dedicated allotments policy, empowerment of local government authorities, and es tablishment of collaborative partnerships between governmental and non-governmental actors. Successful implementation of such a project would also require better streamlining of land ownership data and an ability to ensure security of tenure.
\end{abstract}

\section{Introduction}

Agricultural land abandonment has been identified as one of the dominant land use change processes currently underway in Europe (van der Zanden et al., 2017), with modelling studies predicting a significant increase in abandonment in the region over the next decades (Renwick et al., 2013). The issue of abandonment is complex and contentious, partly because of the lack of a uniform definition of what constitutes abandoned land. Notwithstanding, there has been a clear decrease in cultivated agricultural land in Europe, especially in marginal areas and in small-scale and extensive systems (Renwick et al., 2013; Fuchs et al., 2015), possibly driven by environmental or socio-economic factors, or by combinations of both (Munroe et al., 2013; Terres et al., 2013, 2015). Such abandonment can have positive ecological effects, through vegetation recolonization and secondary succession and through strengthening of a variety of ecosystem services (Novara et al., 2017). However, it can also result in loss of species richness in areas with rich agrobiodiversity (Agnoletti, 2014) and, particularly in the Mediterranean, raises concerns about increased risk of fire and soil erosion (Ursino and Romano, 2014; Jones et al., 2016). In the absence of effective land use zoning and planning mechanisms, abandonment could also potentially open up tracts of currently rural land to urban speculative development (Russo et al., 2014). Indeed, more than $46 \%$ of land converted for urban development within European countries (EEA39) between 2006 and 2012 was originally agricultural (European Environment Agency, 2017).

At the same time, the population of Europe has become increasingly urbanized, with estimates that up to $80 \%$ of citizens could be living in urban areas by 2050 (Cabezas et al., 2016), up from $73 \%$ in 2014 (United Nations Department of Economic and Social Affairs, 2014). Such regional statistics hide significant national-level disparities; the small island state of Malta, for example, which was the focus of this research, has $95 \%$ of its population living in urban areas, while the figure reaches $100 \%$ in Gibraltar. Conversely, Bosnia and Herzegovina

\footnotetext{
${ }^{*}$ Corresponding author at: Room 311, Chemistry \& Pharmacology Building, University of Malta, Msida, MSD 2080, Malta.

E-mail address: elisabeth.conrad@um.edu.mt (E. Conrad).
} 
has a relatively low proportion of $40 \%$ of its population living in urban areas. The increasing urbanization of human populations has been suggested to be a contributing factor to increasing disconnect from nature, with associated negative psychological and physiological consequences (Restall and Conrad, 2015), as well as with impacts on people's level of engagement with and interest in nature (Breuste and Artmann, 2014; Perkins, 2010). In turn, connectedness to nature has been shown to be a key factor influencing environmental behaviour (Gosling and Williams, 2010; Otto and Pensini, 2017). For these and other reasons, there has been growing attention paid to the role that urban green spaces can play within city environments, with these not only providing varied social, economic and ecological benefits (BaycanLevent et al., 2009), but also potentially serving an important environmental justice role (Rutt and Gulsrud, 2016).

Based on the above, this work explores the feasibility of simultaneously mitigating the impacts of agricultural abandonment and providing opportunities for urban residents to engage with nature, by converting abandoned agricultural land in peri-urban areas into community allotment gardens. An allotment garden is defined as a parcel of land, subdivided into cultivable plots that are individually rented out to members of the public for their own private use (Bell et al., 2016). The study focuses on the heavily urbanized context of the Maltese Islands, where population density averages 1361 people per $\mathrm{km}^{2}$ and where more than $30 \%$ of land is built-up, significantly higher than the EU average of $4 \%$ artificial surfaces (European Environment Agency, 2017). For purposes of this work, abandoned agricultural land is taken to refer to parcels upon which active management (Terres et al., 2013) and economic rural activities (Cassar, 2010) have ceased, and that have not been significantly recolonized by natural vegetation, afforested, or converted to other land uses. The study applies an approach based on three pillars necessary for the success of an allotment scheme i.e., availability of suitable land parcels (referred to as place aspects), interest from relevant stakeholders (people), and presence of an enabling policy framework (policy).

The next section of this paper first briefly reviews the historical background of allotment gardens and their societal role. After the study context and research methods are outlined in Section 3, results of the feasibility assessment are presented in Section 4. The final Discussion and Conclusions section reflects on the findings of this study and proposes necessary measures for successful implementation of the proposed land repurposing scheme.

\section{Allotment gardening: a brief review}

Community allotments and gardens have been a fixture of the European countryside for centuries (Bell et al., 2016; Keshavarz and Bell, 2016), and many large European cities have long-standing allotment sites that function as small oases amidst dense urbanization (Foley, 2014; Bell et al., 2016). The allotment experience varies by country. In the UK, for example, allotment history may be viewed as following two distinct routes - that of the rural allotment, initially set up as a means for the poor to be able to feed themselves, and that of the urban allotment, in demand among the relatively wealthy middle class of inner cities (Bell et al., 2016). More broadly across Europe, allotment history has been characterized as evolving over four phases: European industrialization (1700-1910), the World War period (1911-1950), the post-War period (1951-1972) and the revival period (1973-present) (Keshavarz and Bell, 2016). Allotments served different purposes at different points over this history, at times contributing to food security for the poor, at other times providing distractions from the horrors of war, and more recently providing opportunities for reconnection with nature in an era of increased urban disconnect. Many countries have specific legal instruments that regulate the establishment and running of allotments (e.g. Smallholding and Allotments Act of 1908 (UK), Federal Laws on the Regulation of Allotment Gardening 1958 (Austria), Federal Act of Small Garden 1983 (Germany), Allotment Gardens Act
2001(Denmark)).

The benefits provided by allotment gardens have been extensively documented. Studies have shown that allotment sites may contribute to achieving principles of sustainable development (Barthel and Isendahl, 2013; Colding and Barthel, 2013), providing benefits within economic (Perez-Vazquez et al., 2006), social (Soga et al., 2017), and environmental spheres (Acton, 2011). The benefits of allotments can also be assessed through the lens of ecosystem services (Langemeyer et al., 2016), while other studies have shown how allotments can improve the resilience of both natural and urban environments in the face of issues such as climate change (Barthel and Isendahl, 2013; Colding and Barthel, 2013). Of particular interest are studies that highlight the impact allotments have on community empowerment, social cohesion, and the inclusion of marginalized populations (Bishop and Purcell, 2013; White and Bunn, 2017), their ability to foster a sense of connectedness to nature (Church et al., 2015), and the potential health benefits they can provide, especially to senior citizens (van den Berg et al., 2010). These aspects are particularly relevant to the study area of Malta, which has rapidly expanding and increasingly multicultural urban communities, a large urban footprint, an ageing population, and where health issues such as obesity are on the rise, highlighting the need for meaningful and health-enhancing recreational activities (Wood et al., 2016). There is ample evidence that contact with nature through activities such as gardening benefits physical and mental health (van den Berg et al., 2010). Likewise, the ability of allotment gardens to contribute to provisioning, regulating, cultural and supporting ecosystem services (Terres et al., 2013) is highly relevant to the Maltese context, given significant pressures on ecosystems and related issues of habitat loss, fragmentation, and land degradation (Dwyer et al., 2014). The maintenance of such green spaces can also enhance the economic value of specific localities (Özgüner et al., 2012).

Notwithstanding the above, there are also difficulties associated with the allotment concept. For example, while often considered as a form of urban agriculture, since they are generally cultivated by city or town dwellers (Spilková and Vágner, 2016), the extent to which these are made available for community or individual use varies from place to place, leading to ambiguity surrounding their definition. Such a plot area also needs to be made legally available to these individuals or groups, to be used for growing of food or horticultural crops, but generally not for residence (Holmer et al., 2003). Spilková and Vágner (2016) argue that there can be a tension created by individual plot ownership in a context of a general need for green spaces accessible to all citizens. Similarly, allotments have sometimes been characterized as in-between 'third spaces' (DeSilvey, 2003), that are neither places of agricultural production, nor places for passive leisure, and that are characterized by dichotomies - e.g., between private and public, production and consumption, labour and leisure. These ambiguities can create challenges for local authorities to accommodate allotments within their land-use planning systems. Furthermore, experience has shown that successful implementation of allotment projects is dependent on community empowerment and on bureaucracy-reducing procedures that may not necessarily be present (Rego, 2014).

\section{Material and methods}

This section first briefly describes the study area context (3.1); this is followed by a description of the methods adopted to evaluate place (3.2), people (3.3) and policy (3.4) dimensions.

\subsection{The study area}

Malta is one of the smallest EU member states but also one of the most heavily urbanized and densely populated. The agricultural sector makes a minor contribution of roughly $1.65 \%$ to the country's Gross Value Added (National Statistics Office, 2016). The sector employs a total of 19,066 persons, the great majority of which are male and $>45$ 
years of age (National Statistics Office, 2016). The number of persons in active agricultural employment, especially full-time employment, is on the decline. One contributing factor is the small size of land parcels (with $>75 \%$ of holdings of $<1$ ha) (National Statistics Office, 2016), with consequent poor commercial viability; this situation has been exacerbated by inheritance laws that have encouraged progressive subdivision of land over generations. However, the decline in employment is almost certainly also due to the loss of popularity of work in the sector, the general hardships that the work entails, and the availability of alternative career options.

Notwithstanding this decline, agriculture continues to play a strong role in local identity and in shaping landscape character. Agriculture is Malta's largest land user, taking up just under $50 \%$ of the total land surface of the Islands. A total of 11,689 ha are currently registered as utilized agricultural land (UAL) (National Statistics Office, 2016), with $(<200$ ha) characterized as unutilized agricultural land (UuAL); the latter is at significantly higher risk of degradation due to neglect, lack of maintenance, and encroaching development (Government of Malta, 2015). The abandoned agricultural land that this study will target is likely to fall under this category. Much of this land has, however, been abandoned with reason: it is either marginal, of poor quality, difficult to access, or unfeasibly small (Government of Malta, 2015). These factors were considered further during the site selection process discussed in Section 3.2 below. The declining prospects of the agricultural sector across the Islands arguably need to be addressed, not only to help preserve Malta's identity but also to mitigate the increased risk of land degradation by restoring parcels of land to productivity, increasing resilience (Dwyer et al., 2014).

The dearth of urban green space in Malta is a further relevant consideration. As noted above, Malta has a disproportionately high degree of urban land cover, which incorporates within it only relatively few green spaces. Such spaces are known to contribute positively to recreation, health, biodiversity conservation, cultural identity, nature connectedness, and environmental quality (Kabisch et al., 2016). In a survey of the general Maltese public, Restall (2017) ${ }^{1}$ found that $61 \%$ of respondents considered access to public gardens, parks, countryside or other public spaces to be very important and a further $33 \%$ considered it fairly important, for reasons including rest and relaxation, spending time in nature, health and physical activity, and social interaction. However, Vincenti and Braubach (2013) note that almost a fifth of the population of Malta has difficulty accessing green and recreational spaces (even if such spaces have increased somewhat over recent decades) and highlight this as a significant public health challenge for Malta; (it is worth noting that obesity is also a significant national health concern). In this context, there is a clear role for more innovation in the provision of green spaces for community use, including for active outdoor engagement. To date, allotment initiatives have been limited in extent and rather short-term, with only two such projects on record, neither of which remains in operation today.

\subsection{Place: availability of suitable land}

In order to identify candidate sites for conversion to community allotment gardens, a methodology was developed based on guidance provided in the literature but taking specific account of the physical characteristics of the Maltese Islands. A terrestrial habitats dataset which includes an 'Abandoned Agriculture' category was obtained from the local Planning Authority (PA) and imported into ArcMap 10.5. Data was cleaned and transferred to Google Earth Pro (Fig. 1). Satellite imagery available on Google Earth Pro was then used to verify the accuracy of PA data; a number of mapping errors were noted and corrected. Historical satellite imagery from Google Earth Pro for the period 2006-2016 was then used to verify the abandoned status of

\footnotetext{
${ }^{1}$ Unpublished PhD thesis, University of Malta, December 2017
}

individual mapped land parcels, through an analysis of any evident changes in surface characteristics over time and to confirm prolonged absence of ploughing, crop planting, or other agricultural activities. Fields that were not observed to be under crop were marked as potentially abandoned and highlighted for further analysis. Satellite imagery was also used to check for any parcels of land not included within the Planning Authority's 'Abandoned Agriculture' layer but that could potentially meet abandonment criteria.

Identified land tracts were then visited and evaluated in situ with respect to two sets of criteria: (i) criteria to confirm that the site can be accurately classified as abandoned agricultural land, synthesised from local literature relating to characteristic of abandoned agricultural land (Lanfranco and Cassar, 2003; Cassar, 2010) (Table 1) and (ii) criteria to assess the suitability of the site for conversion to community allotments (Table 2). The latter were selectively compiled following an analysis of criteria identified in academic and other literature (with key sources including Ironside Farrar, 2009; Vale of Whitehorse District Council, 2017; La Rosa et al., 2014; Bath and Northeast Somerset Council, 2015; Horsted Keynes Parish Council, 2017). Several criteria (e.g., site access, current land use) were commonly used across multiple criteria systems. Generally-applicable criteria and other criteria considered most appropriate for the Maltese context were shortlisted; some were adopted for use in this study without modification, while others were modified to be more locally relevant. Examples of such modifications include surface topography and water availability and quality; these were given particular attention considering the tendency for abandoned agricultural land in Malta to be located on steep slopes and in water-scarce environments. Additionally, observable signs of degradation such as evidence of dumping of construction debris, and other forms of potentially hazardous refuse were also incorporated into the soil surface quality criteria. Only sites that met the criteria listed in Table 1 were evaluated for suitability. Table 3 outlines additional considerations that were taken into account in the analysis of suitability. On-the-ground site analysis was carried out via walkover and drone (DJI Phantom 4) surveys.

\subsection{People: interest from stakeholders}

Relevant stakeholders were first identified through a systematic stakeholder analysis exercise, through which their interests were identified, importance and influence assessed, and interactions between them considered. Three main groups of stakeholders were identified: local communities, relevant organizations/institutions, and governmental stakeholders. Members of the local community are the intended beneficiaries and users of allotment sites; it was therefore crucial to gauge their interest in such an initiative. Governmental authorities (especially local government represented by local councils) were approached due to the important role that government entities play in allotment site provision and protection (Gant et al., 2011). Finally, organizations have the potential not only to be users of allotments but also to manage such sites directly, possibly acting as intermediaries between communities and government agencies. Organizations contacted included environmental non-governmental organizations and scout groups.

Members of the local community were engaged via door-to-door interviews. In total, 50 local residents from each of the three localities considered (discussed in Section 4) were interviewed face-to-face, for a total of 150 respondents. In order to maximize the utility of data obtained, participants were not selected at random; instead, denser and more urbanized communities, as well as communities directly in the vicinity of the selected sites were preferentially sampled. This was based on findings in the literature indicating that residents lacking gardens or access to other public or private green spaces were more likely to be interested in and benefit from local allotment projects. However, efforts were made to obtain a fairly even age and gender distribution. Efforts were also made to randomize responses, by 


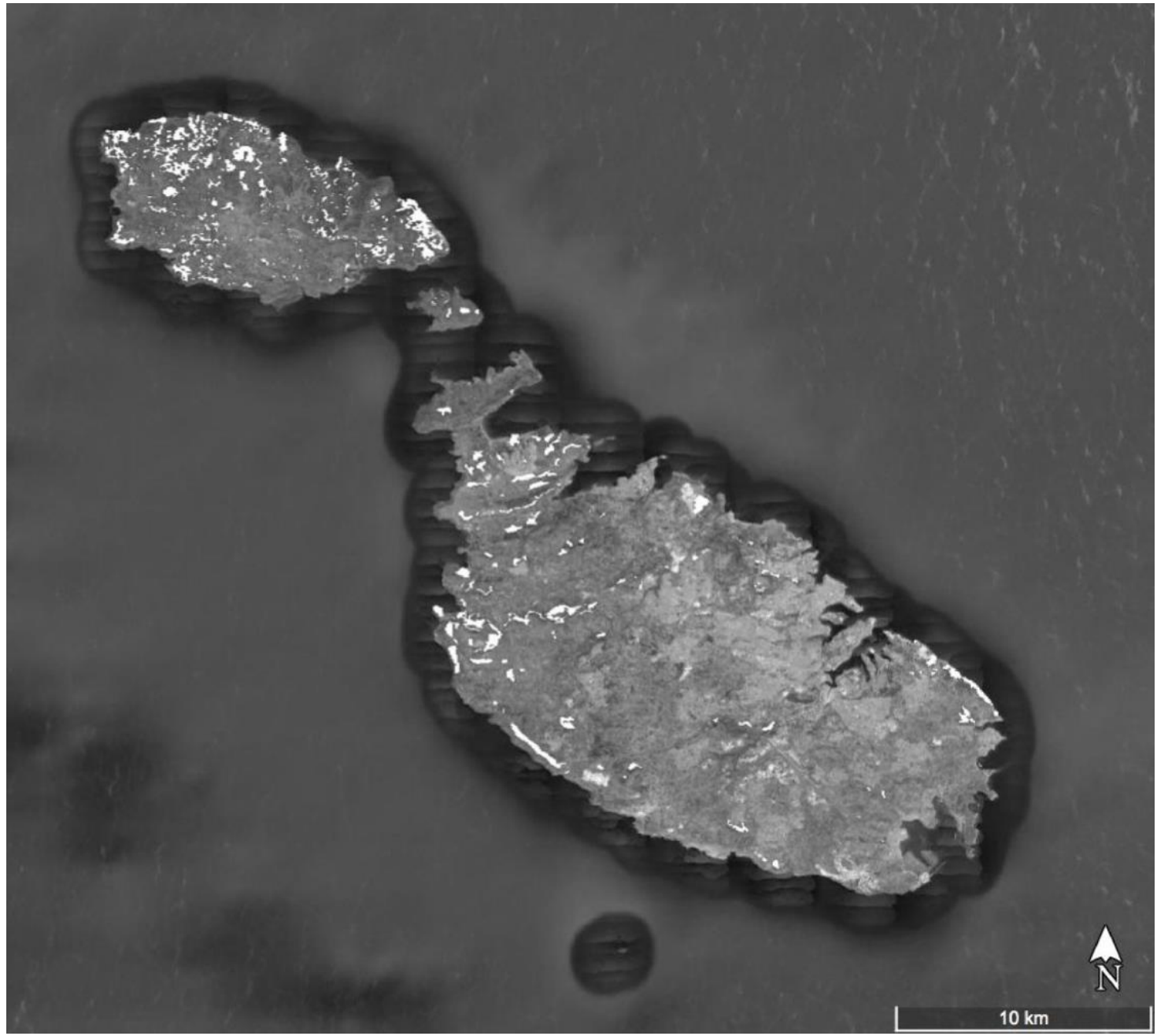

Fig. 1. Identified parcels of abandoned agricultural land (in white) across the Maltese Islands. (source: Google Earth Pro).

Table 1

Land abandonment identification criteria.

Adapted from Lanfranco and Cassar (2003) and Cassar (2010).

\begin{tabular}{ll}
\hline Factor & Indicators \\
\hline Vegetation & Presence of secondary succession \\
& $\begin{array}{l}\text { Presence of ruderal communities } \\
\text { Boundaries }\end{array}$ \\
& Rubble wall condition \\
& Extended coverage of Opuntia ficus-indica (Prickly Pear) and/or \\
& Arundo donax (Great Reed) \\
Edaphic factors & Soil condition \\
& Evidence of erosional processes
\end{tabular}

${ }^{a}$ Both these species are commonly used as field boundary delineators within the Maltese Islands and can spread if not controlled.

conducting visits at different times of the day and on different days. Data gathered through interviews was predominantly qualitative (with key discussion themes shown in Table 4); collected data was thematically coded, with identified themes then used to analyse the spectrum of views and their relative frequencies. Quantitative data elements were also collected, including through dichotomized yes/no questions, questions relating to Willingness to Pay, and questions related to demographics. It is acknowledged that sample sizes are not representative of the populations of the three localities; however, representativeness was not a key aim of this work. Given that this was an exploratory study, the primary intention was to gauge whether there is likely to be interest from members of the community in such an allotment project. To capture the views of other stakeholders, eight local government and organization representatives were engaged individually via face-toface semi-structured interviews (Table 5). Respondents represented two local councils, a governmental agricultural agency, two environmental NGOs, a manager of a restoration project in one of the localities analysed, a scout group, and a local expert on green infrastructure. The qualitative data obtained was analysed thematically (Section 4.2.2 and 4.2.3).

\subsection{Policy}

Local policy pertaining to land use in the Maltese Islands was reviewed to gain an understanding of aspects relevant to establishment of such an allotment project. This identified a handful of documents, with the most relevant being the Strategic Plan for the Environment and Development (SPED) (Planning Authority, 2015) and the Rural Development Programme for Malta (RDP) (Government of Malta, 2015), and with more marginal contributions from other legal and policy initiatives. While both the SPED and RDP highlight the need to safeguard Malta's rural character by preserving pockets of agricultural land and increasing the involvement of local populations in these areas, neither makes any direct reference to community allotments or similar schemes. Relevant policies specific to the three localities selected and included in Local Plans were also reviewed; again, no specific references to allotments were present. 
Table 2

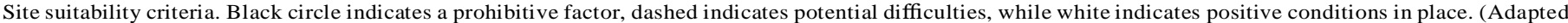

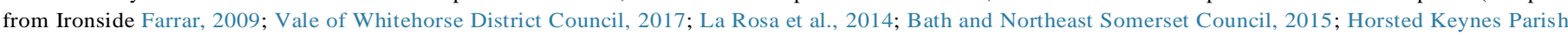
Council, 2017).

\begin{tabular}{|c|c|c|}
\hline Criteria & Aspects & Possibilities \\
\hline \multirow[t]{4}{*}{ Deliverability of the site } & Physical site accessibility & - Access cannot be secured. \\
\hline & & $\begin{array}{l}\text { Access is not ideal but could be possible by design (may not be accessible by vehicle). } \\
\text { There is existing suitable access that can be utilized and/or improved upon. }\end{array}$ \\
\hline & Likely timescale for availability & $\begin{array}{l}\text { - Not likely to be available except in long term. } \\
\text { Land likely to be available in medium term ( } 5-10 \text { years) or available for short term use. } \\
\text { Currently available or likely to be available in short term. }\end{array}$ \\
\hline & Potential number of plots/available space & $\begin{array}{l}\text { Limited land size/not feasible to bring the land to productive use. } \\
\text { Large enough to justify costs even if limited space. } \\
\text { Has potential to provide suitable opportunities for conversion to allotments. }\end{array}$ \\
\hline \multirow[t]{3}{*}{ Productive potential of site } & Known soil/surface water quality & $\begin{array}{l}\text { - Unsuitable soil/water condition/no alternatives available (raised beds/soil carting/ } \\
\text { water catchment). } \\
\text { Suitable soil/water can be achieved. } \\
\text { Recent history of similar land use. }\end{array}$ \\
\hline & $\begin{array}{l}\text { Availability of utilities (including water } \\
\text { provision) }\end{array}$ & $\begin{array}{l}\text { - No current provision and high cost associated with providing utilities. } \\
\text { Some form of water supply/catchment with potential for improvement. } \\
\text { Existing access to water supply and other utilities. }\end{array}$ \\
\hline & Topography constraints & $\begin{array}{l}\text { - Steep slopes or other unsuitable terrain. } \\
\text { Need for a manageable level of remediation. } \\
\text { Limited or no remediation needed. }\end{array}$ \\
\hline \multirow[t]{2}{*}{ Accessibility from local community } & Proximity to urban residences & $\begin{array}{l}\text { - Far from urban residences. } \\
\text { Reasonable distance from urban residences. } \\
\text { Close proximity to urban residences. }\end{array}$ \\
\hline & Pedestrian access/walking distance & $\begin{array}{l}\text { - }>30 \mathrm{~min} \text { walk }(1 \mathrm{~km}) \text { or unsafe access. } \\
\text { Reasonable distance }(<20 \mathrm{~min}) \text { and safe. } \\
\text { Well located and safely accessible. }\end{array}$ \\
\hline
\end{tabular}

Table 3

Other site suitability considerations.

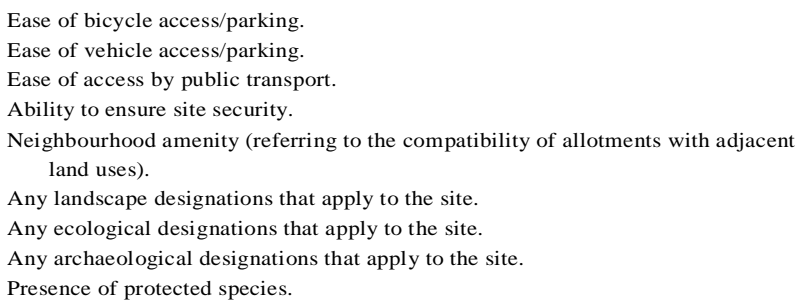

Table 4

Overview of key discussion themes for interviews with local communities.

Before I explained, did you know what community allotments were?

- Do you think these can provide benefits to the environment, to your community, and/or to you personally? What sort of benefits? Are there any costs that you envisage?

- Would you be in favour of an allotment project in your locality?

- Would you personally be interested in renting a plot? If so, would you be willing to commit to plot rental in the long-term? How much would you be willing to pay per month in rental fees?

- Do you think allotments are appropriate for Malta? Are they likely to work? Are there alternative approaches that you would prefer?

- What are your views on community/urban agriculture/agricultural abandonment generally?

(Further respondent details were also documented, including knowledge of gardening, perceived amount of free time, attitudes to the outdoors/nature, and household size, together with demographic data).

\section{Results}

\subsection{Place: availability of suitable land}

Following the analysis detailed in Section 3.2, three localities with potentially suitable land in their peri-urban areas were shortlisted: Mosta (on the main island of Malta), Qala, and Cittadella (both on the smaller island of Gozo) (Fig. 2). Specific tracts of land were identified within each of these localities. This does not mean that available land is not available elsewhere; indeed, as shown in Fig. 1, there is potentially suitable abandoned agricultural land distributed across the Maltese Islands. However, the aim of this study was not to exhaustively analyse all abandoned land but rather to conduct an initial analysis of potential feasibility, in the process testing the developed criteria. The three selected localities were considered to be particularly well suited to such analysis because they represent a range of peri-urban conditions.

\subsubsection{Locality 1: Mosta}

Mosta was selected as the first case study area, among other reasons because it has a near-complete 'green belt' around it, broken only by its link to the neighbouring town of Naxxar, and because previous studies have indicated the presence of abandoned agricultural patches (Sultana, 2015). The town has a resident population of $>20,000$ (Government of Malta, 2014). Analysis of satellite imagery revealed a clear increase in the extent of development and consequent urban encroachment in recent years. Three specific tracts of land were identified within the locality, with these henceforth referred to as MST 1, MST 2, and MST 3 (Fig. 3). All sites were confirmed to contain abandoned parcels, with evidence of secondary succession and/or colonization by ruderal communities and lack of maintenance of field boundaries in all three cases. MST 1 appeared to have been used for (illegal) dumping of construction waste. MST 2 supported thick vegetation; in this case, abandoned land parcels are interspersed within a mosaic of actively cultivated small fields and plots supporting natural vegetation. MST 3 is also comprised of a mosaic, of long abandoned and recently abandoned agricultural plots, some sparsely utilized plots of patchy soil, relatively natural garrigue, and patches degraded through dumping of construction and other waste.

The three sites were assessed in terms of the criteria discussed above. MST 2 (Fig. 4) was shown to best meet requirements. This site has the potential to provide suitable space for allotments (roughly $20,000 \mathrm{~m}^{2}$ ). Physical access to the site is possible with relative ease, there is good potential for securing water supply, and little or no physical soil remediation would be needed. The site also benefits from being in close proximity to urban residences, within easy and safe 
Table 5

Key discussion themes addressed in qualitative interviews with organisational stakeholders.

Local councils

Project manager

Governmental agency

NGOs (specific discussion themes tailored according to NGO experience)
Is there a problem with agricultural abandonment in your locality?

What are your views on developing community allotments in Malta?

What would the interest of the Local Council be, and what role could it play? Does the Local Council have any relevant experience?

What is the current status of agricultural land parcels within the project area?

What are your views on developing community allotments in Malta? What role could community allotments play within the context of the project Masterplan?

How would you rate the success of previous allotment projects and why?

How did such projects come about?

What were the benefits and costs?

What helped and what were the issues encountered?

Is there any potential for allotments being put back on the agenda?

How would you rate the success of previous allotment projects and why?

How did such projects come about?

What were the benefits and costs?

What helped and what were the issues encountered?

What are your views on developing community allotments in Malta?

Does the NGO have any relevant experience? What role can NGOs play in such projects? What interest would your

NGO have in such a project? Is there any potential for allotments being put back on the agenda?

Specialist

What are your views on developing community allotments in Malta?

Is there a problem of agricultural abandonment in Malta? What would be needed for successful implementation of community allotments in Malta?

What are your views on developing community allotments in Malta?

What would the interest of scout groups be, and what role could they play? Do scout groups have relevant experience? walking distance. MST 3 (Fig. 5) could potentially be suitable, but the site would require remediation. Furthermore, conversion to allotments could be constrained by the presence of protected archaeological remains. MST 1 is also potentially suitable but dumped waste would first need to be removed and the soil tested for contamination to ensure suitability for cultivation.

\subsubsection{Locality 2: Qala}

Qala is a relatively small town, with just under 2300 residents (Government of Malta, 2014), but with a slowly growing urban footprint. The motivation for selecting Qala was, in large part, the presence of large tracts of abandoned agricultural land in its immediate surroundings, also confirmed in previous studies (Cassar, 2010; Sultana, 2015). The aesthetic appeal of the town, which affords commanding views of the neighbouring islands of Comino and Malta, could also potentially be enhanced by converting abandoned agricultural land to actively cultivated allotments. Furthermore, the entire island of Gozo is known to support a substantial resident expatriate population, who specifically seeks out Gozo for its more rural qualities and who may therefore be particularly interested in such a scheme. Analysis revealed

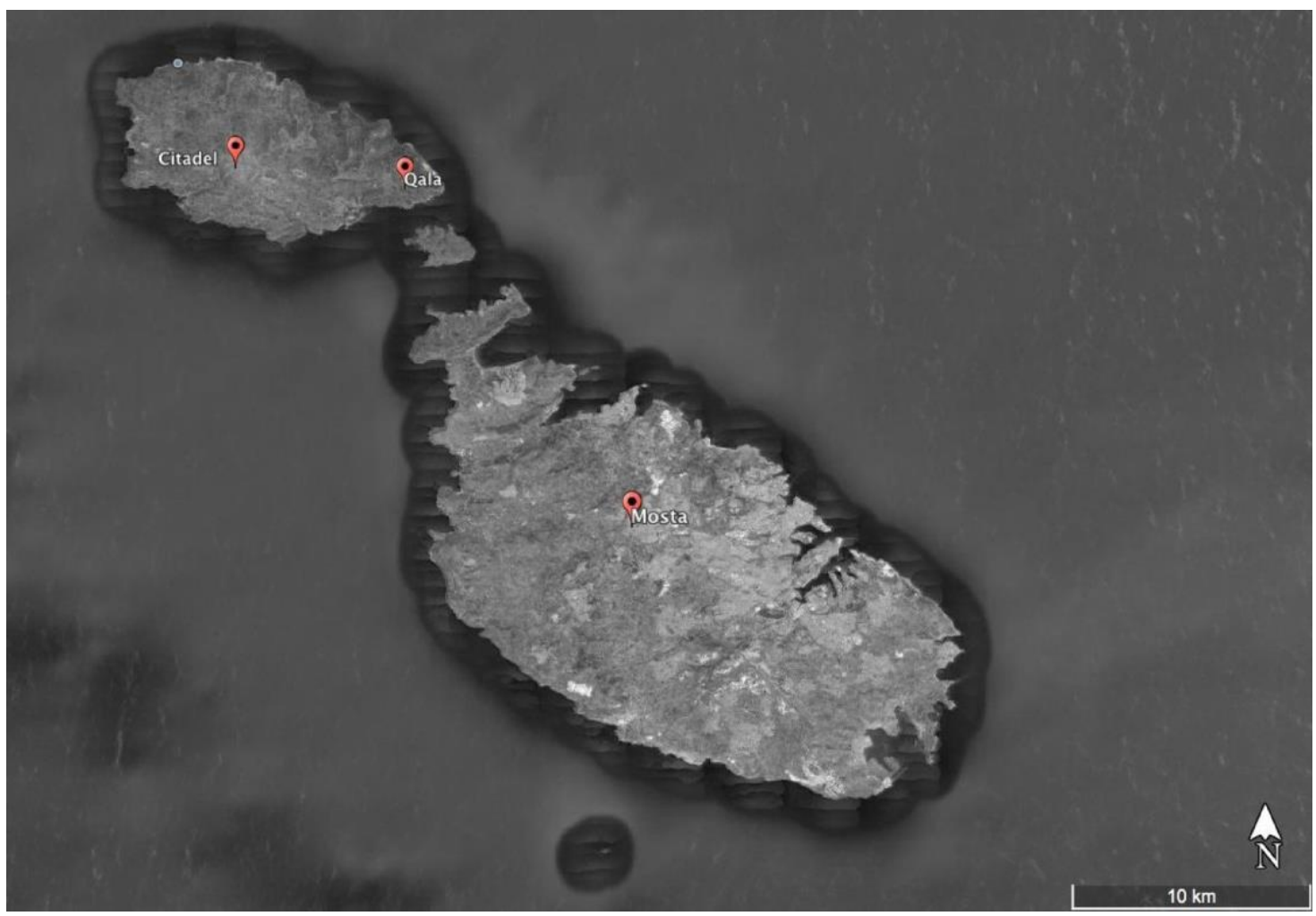

Fig. 2. Localities shortlisted for further investigation.

(source: Google Earth Pro). 


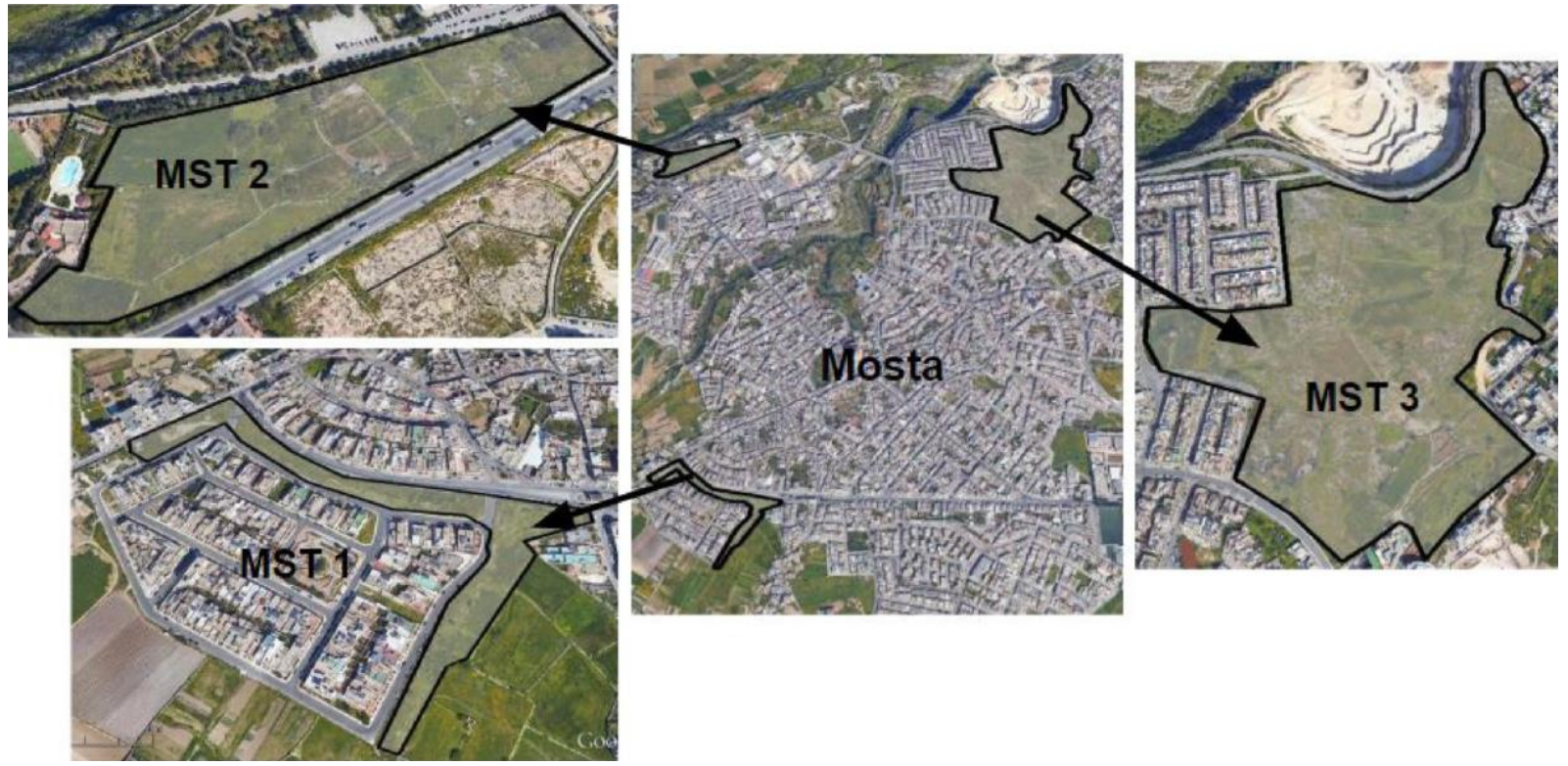

Fig. 3. Identified land parcels in Mosta (MST 1, MST 2, and MST 3).

(source: Google Earth Pro).

two potentially appropriate areas (Fig. 6): QLA 1, located to the south of the town and directly adjacent to a number of residences, and QLA 2 to the east of the town. Both sites are comprised of a mosaic of utilized and abandoned agricultural parcels, as well as parcels containing relatively natural vegetation. Ground truthing enabled identification of specific abandoned parcels within both areas.

QLA 1 (Fig. 7) meets all site suitability criteria; it can be easily accessed by the local community and offers good scope for deliverability, productive potential, and water capture. Little remediation would be required, as the plots are in reasonably good condition. QLA 2 (Fig. 8), on the other hand, would require extensive remediation to restore terraces and field boundaries. Access is also an issue, with the site located at some distance from urban residences and on steep and exposed terrain that would potentially make cultivation difficult.

\subsubsection{Locality 3: Cittadella}

The Cittadella area, a fortified citadel, was the subject of a recent Masterplan (Government of Malta, 2011), which included as one of its critical objectives, reclamation of abandoned agricultural parcels on hill slopes surrounding the citadel and of small plots of abandoned land lying within the citadel walls. The Masterplan pays particular attention to the issue of abandonment because this is considered to be contributing to degradation of the landscape's cultural and ecological value. The Masterplan specifically recommends re-establishing links

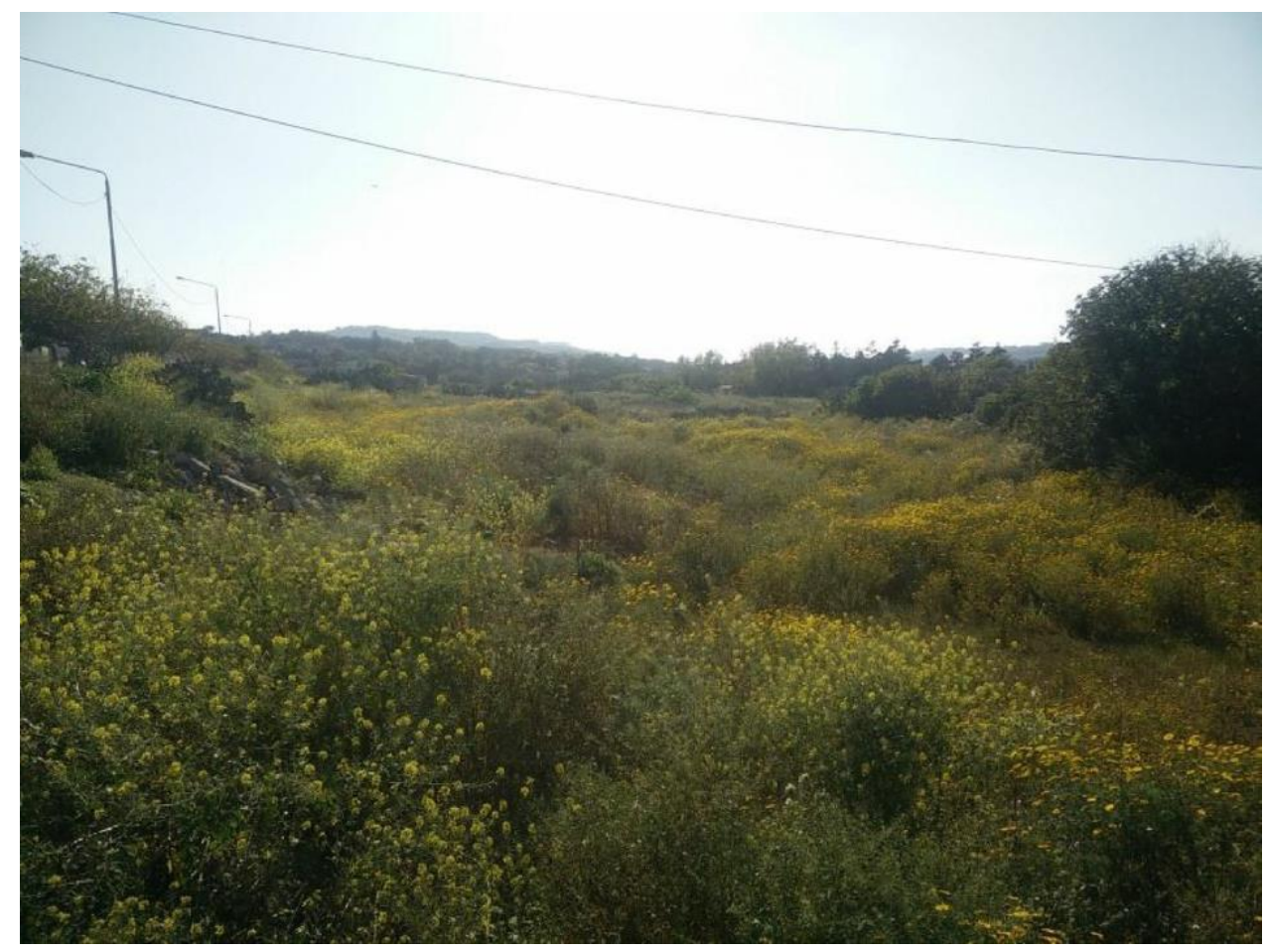

Fig. 4. Current status of MST 2 site. 


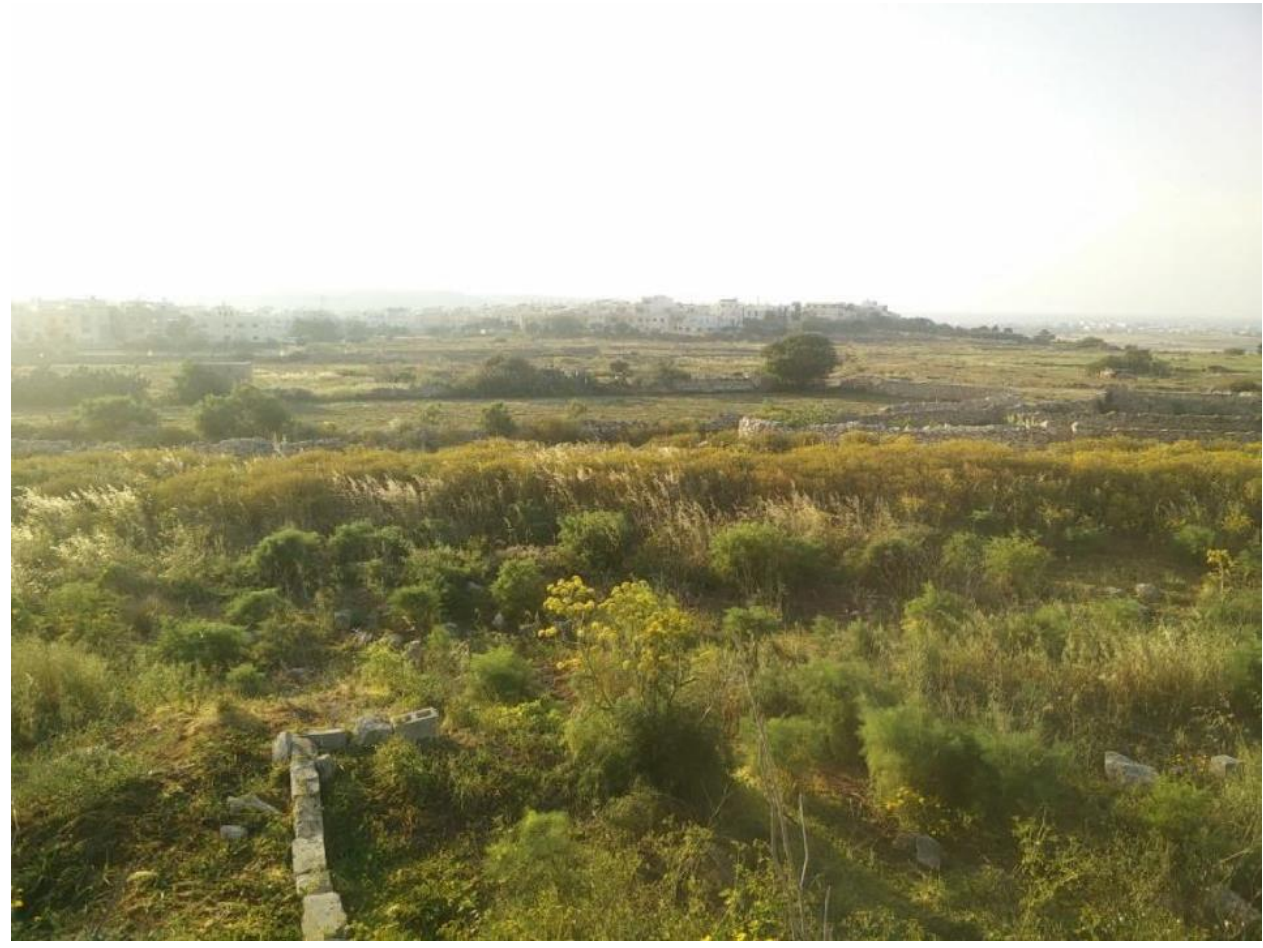

Fig. 5. Current status of MST 3 site.

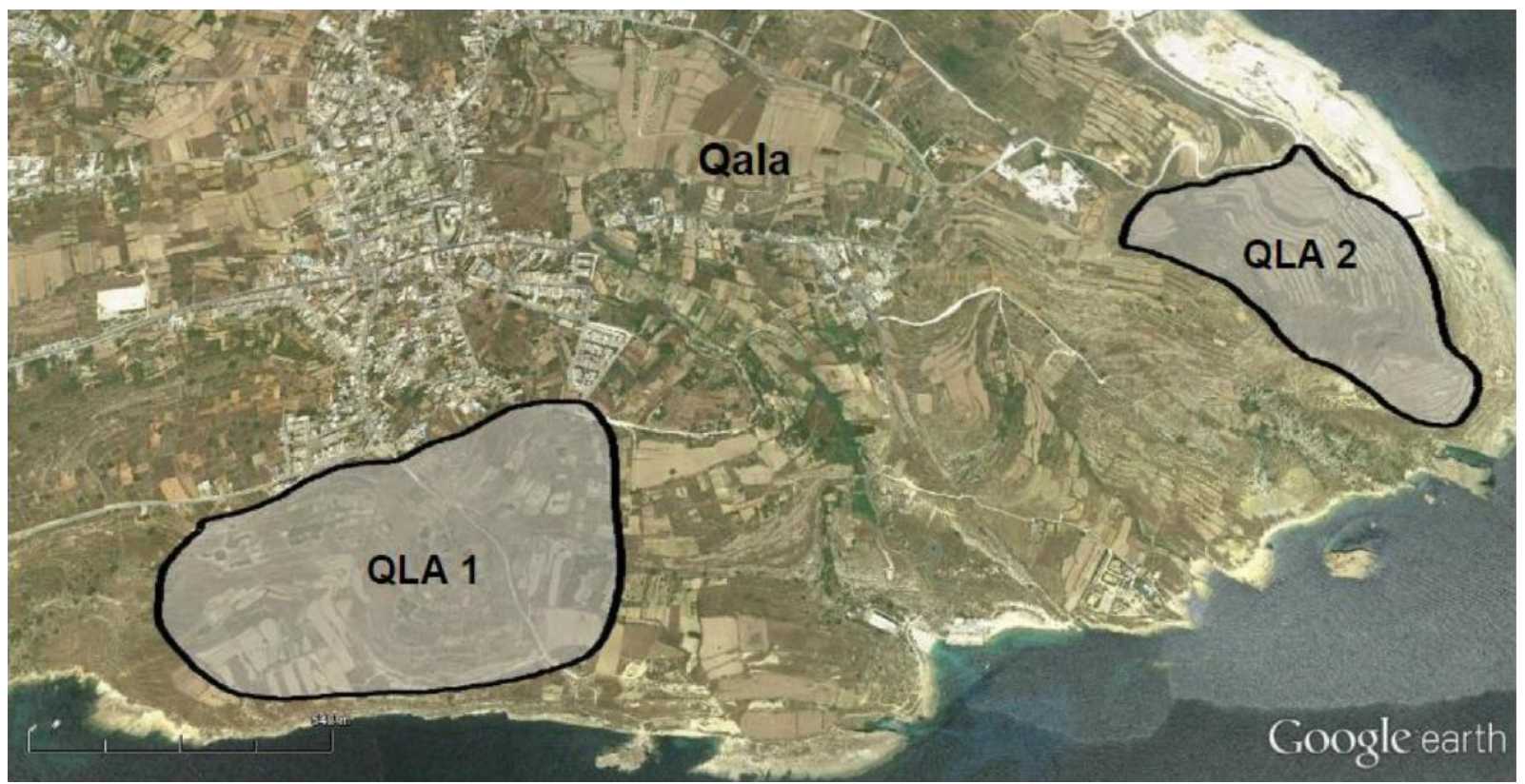

Fig. 6. Identified land parcels in Qala (QLA 1 and QLA 2).

(source: Google Earth Pro).

between the Cittadella and traditional agricultural practices. As in the case of other sites, the abandoned status of land parcels documented in previous studies (Cassar, 2010; Sultana, 2015) was confirmed, and additional abandoned parcels were also identified. On the basis of this analysis, three sites were identified for more detailed analysis (CTD 1, CTD 2, and CTD 3) (Fig. 9). The abandoned status of all three sites was confirmed.

CTD 1 (Fig. 10) appears to offer the best potential for conversion to allotments in the short term. Ease of access would possibly facilitate uptake by the local community and the site would require little remediation. It also has good opportunities for water catchment from the overlying citadel. CTD 3 (Fig. 12) was also found to be moderately suitable, but likely to be subject to some constraints due to the presence of several features of archaeological importance. CTD 2 (Fig. 11) could theoretically be suitable but faces access constraints, being located on steep terrain that can only be accessed on foot, and at some distance (> $1 \mathrm{~km}$ ) from urban residences. It is also likely to require some degree of remediation to be able to support production. 


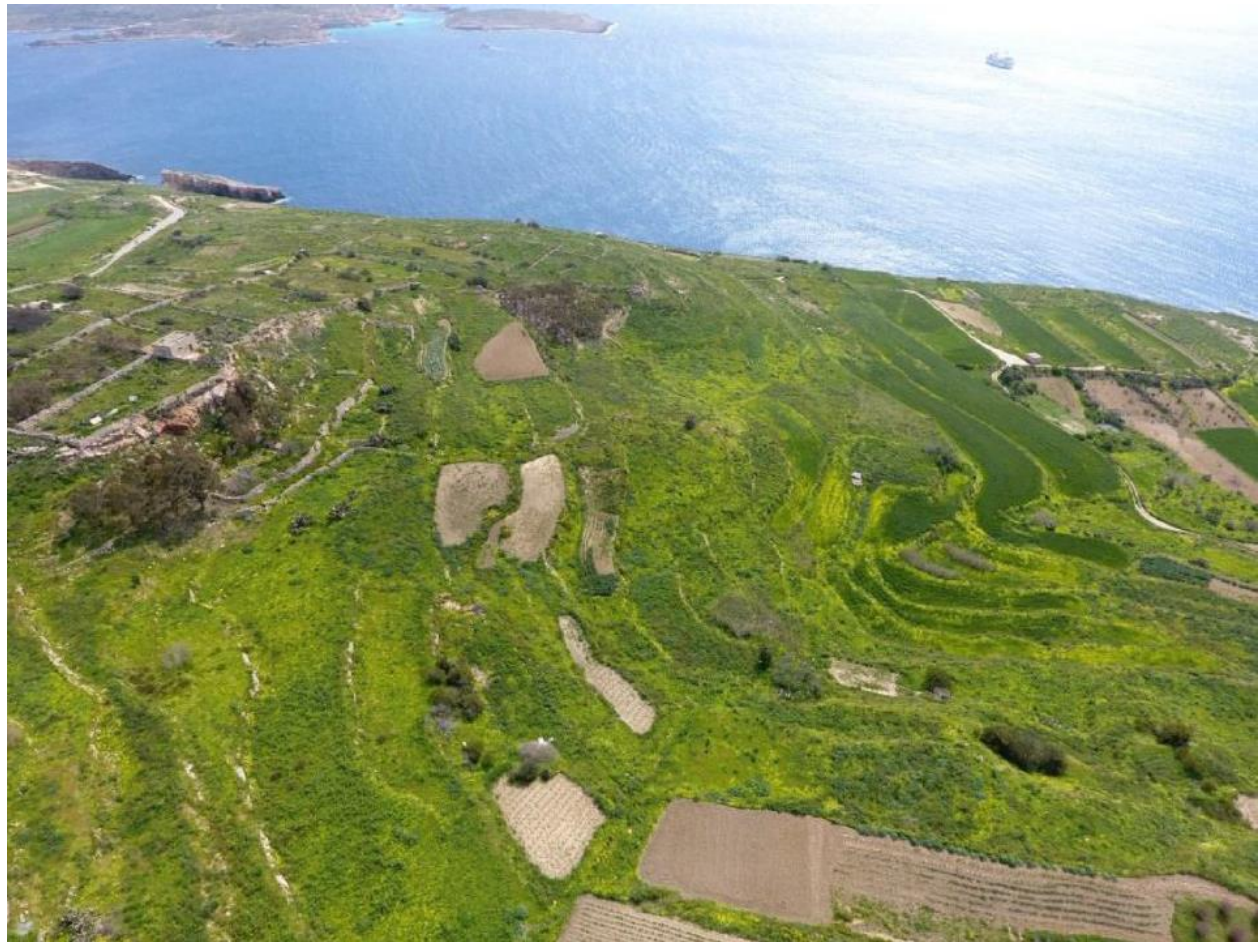

Fig. 7. Current status of QLA 1 site.

\subsection{People: stakeholder interest}

\subsubsection{Members of the local community}

In order to avoid misunderstandings, the concept of community allotment gardens was first explained to respondents during interviews. Respondents were then asked if they had any previous familiarity with this concept. The majority (79\%) had no such familiarity, with only $15 \%$ of respondents considering themselves to have a good understanding of what allotments are. Notwithstanding, $81 \%$ of respondents considered the provision of allotment gardens (as explained to them) to potentially be beneficial to society and/or the environment. Potential environmental benefits cited by respondents included increasing greenery, improving the status of biodiversity, improving air quality, increasing soil fertility, and providing a degree of protection from development. Social benefits identified included the establishment of stronger connections with nature, opportunities for relaxation and

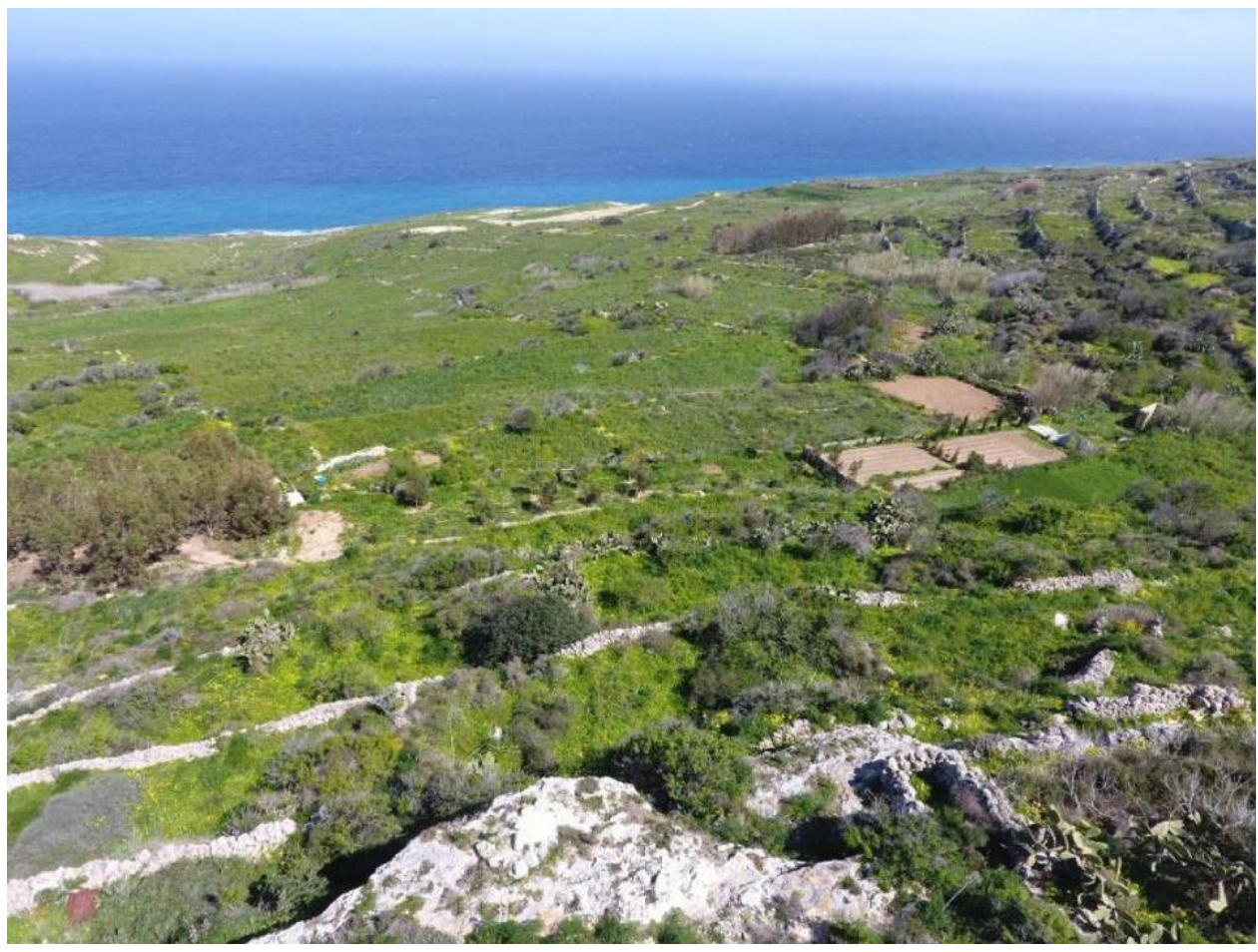

Fig. 8. Current status of QLA 2 site. 


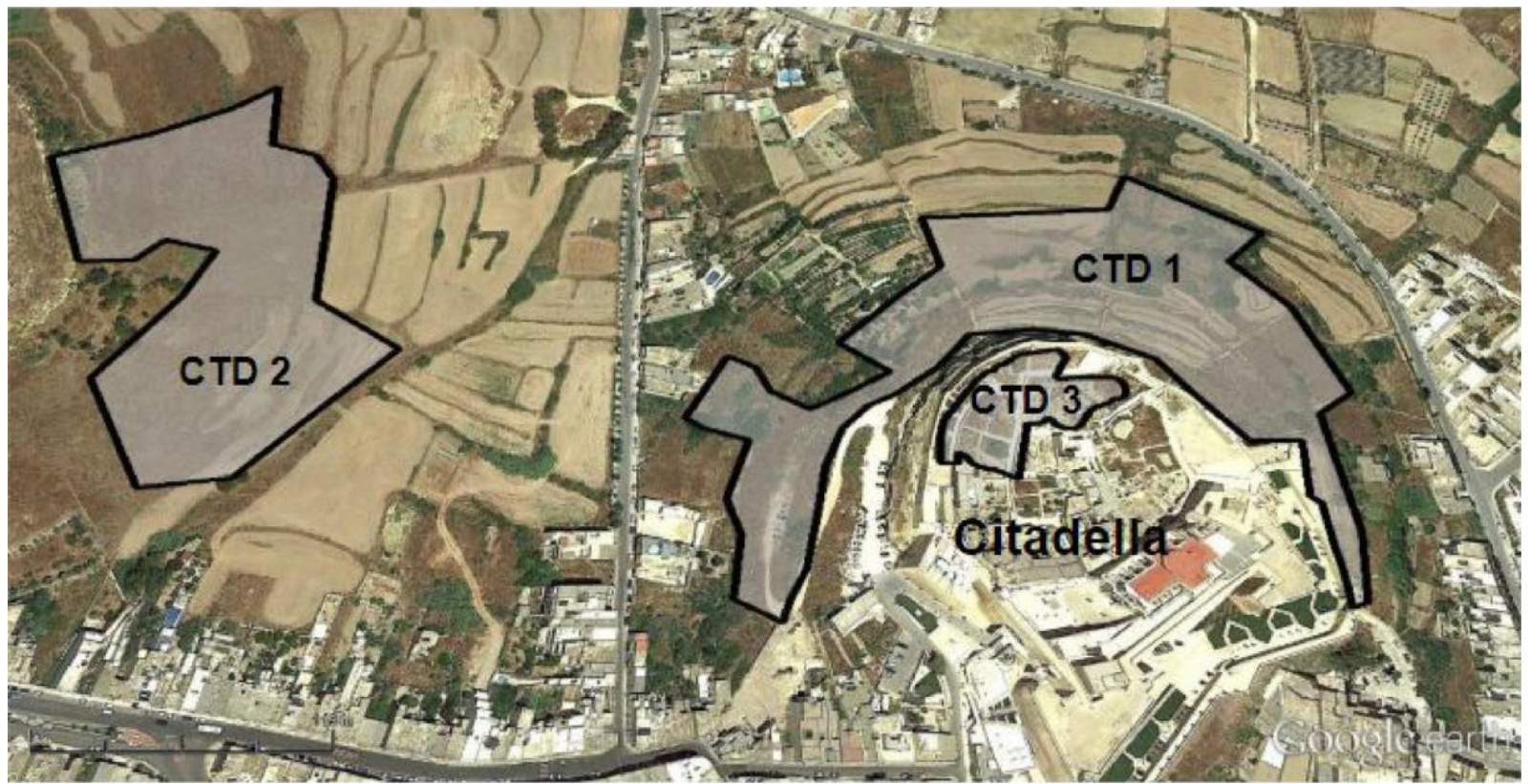

Fig. 9. Identified land parcels around the Cittadella, Gozo (CTD1, CTD2, CTD3). (source: Google Earth Pro).

recreation, the provision of healthy (possibly organic) food, opportunities for shared family/community activities, and educational opportunities. As a follow-up question, respondents were then asked if they would be in favour of the provision of allotment gardens within their own localities. Responses were again predominantly positive $(75.3 \%$ in favour), albeit with some minor differences between the three localities. Respondents who were not in favour expressed a number of concerns, including potential disruption of traditional activities such as bird hunting and trapping, disruption of peace and quiet due to increased influxes of allotment farmers, and potential negative impacts from mismanagement or neglect. A further concern was the potential impact of such a scheme on land ownership rights. These concerns appeared to be particularly important to Gozo residents. Participants who were in favour of allotment garden provision were also asked about their own personal interest in renting a plot should one become available in their locality. Results were relatively consistent across localities, with interest expressed by 36\%, 36\%, and 29\% of individuals in Mosta, Qala, and Rabat, respectively. Many of those who expressed interest explained that their intentions would be primarily recreational rather than food production; this is consistent with general trends from contemporary literature on allotment gardens across Europe (Breuste and Artmann, 2014; Church et al., 2015). Those who were not interested in

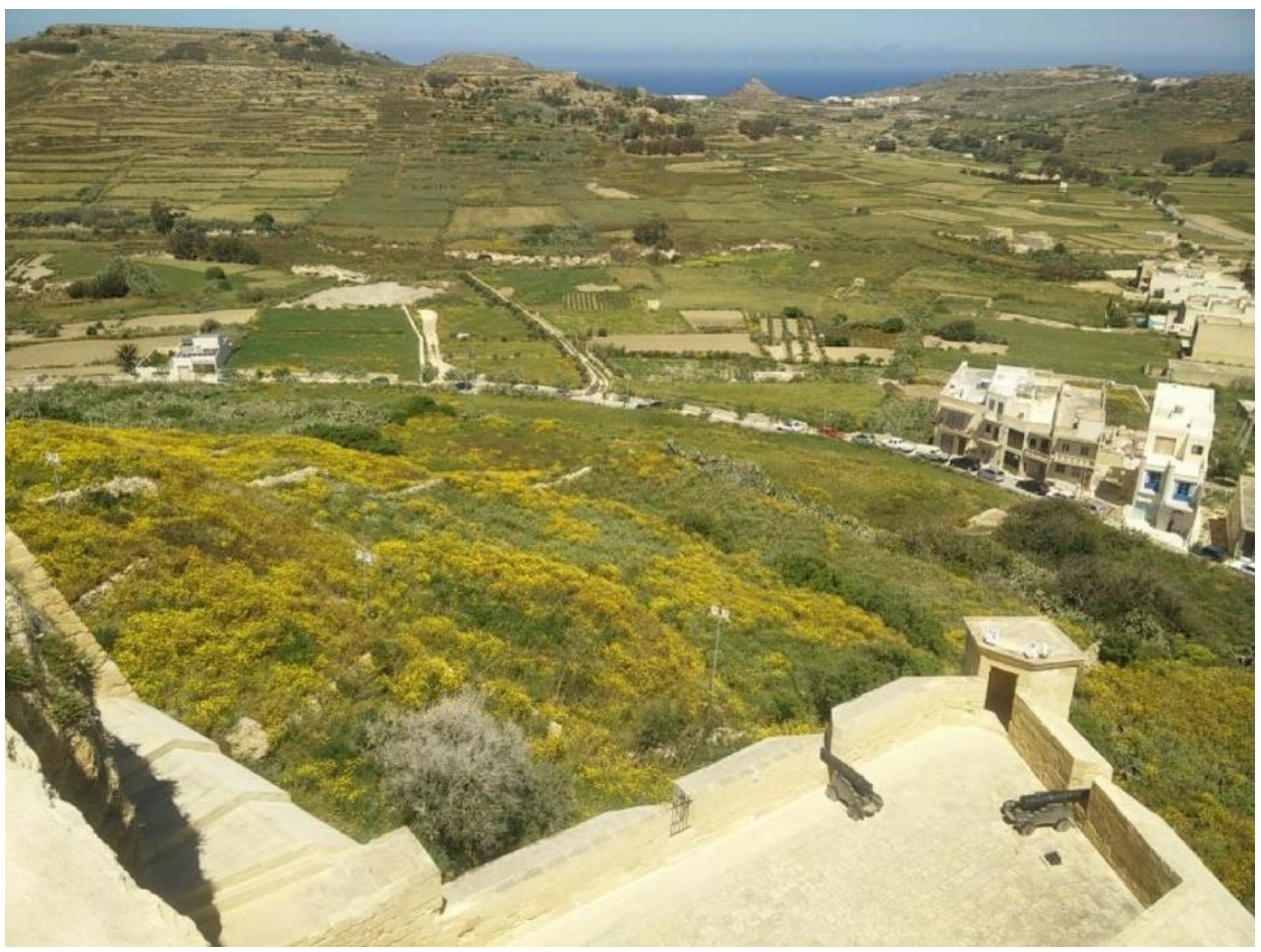

Fig. 10. Current status of CTD 1 site. 


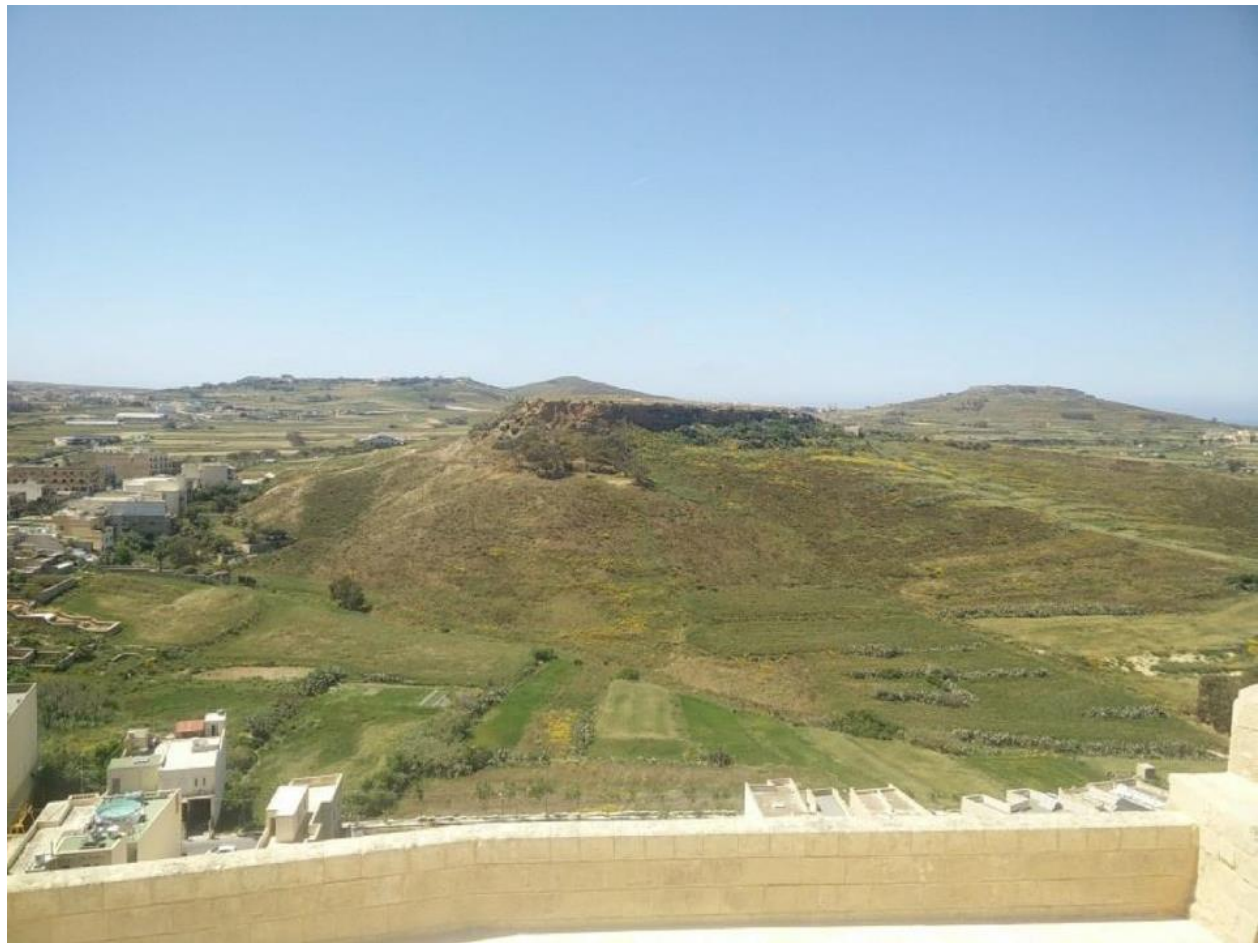

Fig. 11. Current status of CTD 2 site.

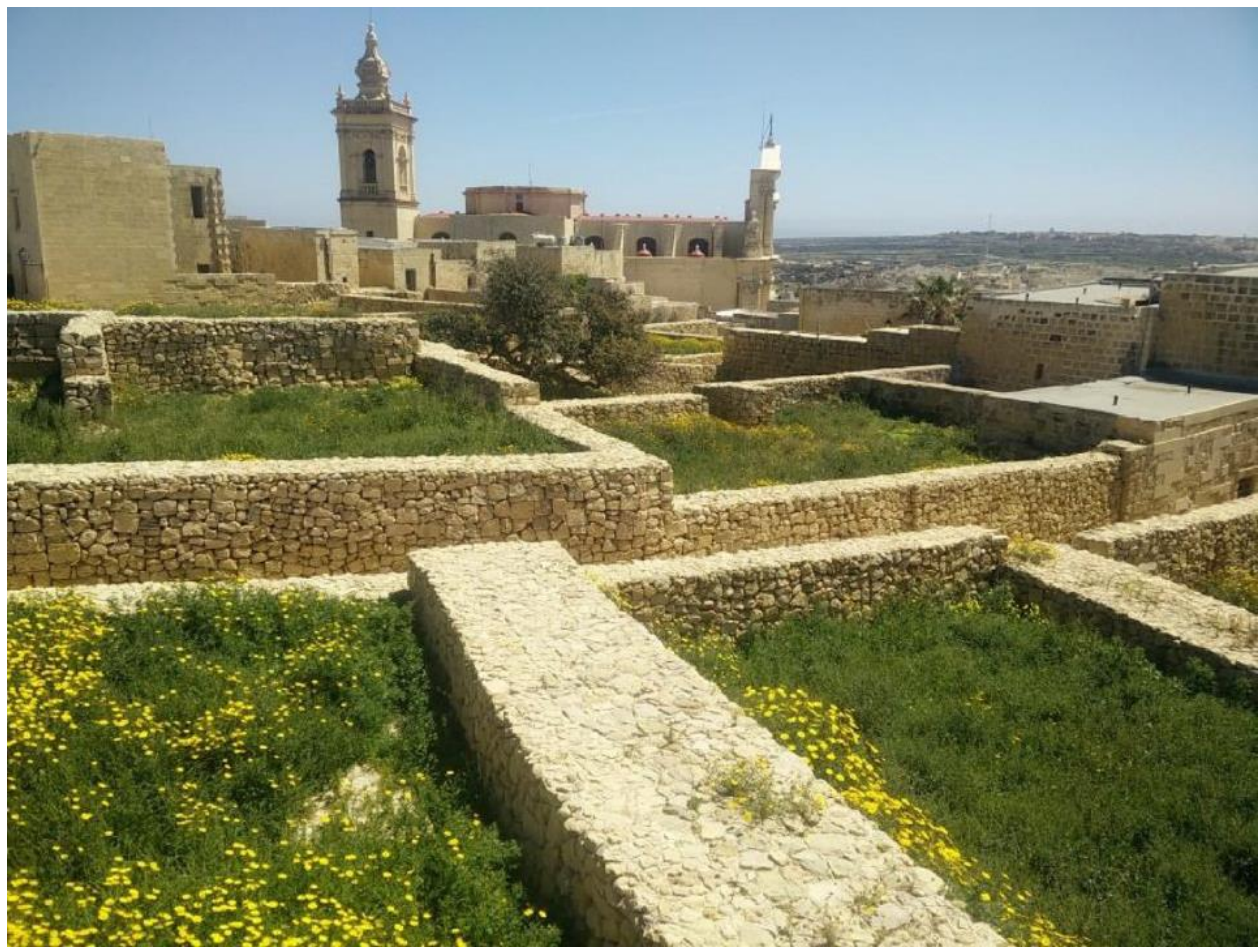

Fig. 12. Current status of CTD 3 site.

plot rental cited reasons including physical limitations (age or mobility issues), a lack of interest in gardening, and already owning agricultural land parcels.

Since interest in renting a plot was considered to be the critical variable related to social feasibility of setting up allotment schemes, its relationship with other variables was analysed more closely. Gardening knowledge (p-value 0.001), age (p-value 0.0, Fisher's Exact 0.006), and level of education (p-value 0.030, Fisher's Exact 0.022) were found to be significantly related to interest in renting a plot. Individuals with basic or good knowledge of gardening were significantly more likely to be interested in plot rental; those with very good knowledge tended to already be engaged in gardening activities. Individuals aged between 31-40 were most likely to express interest, followed by those aged 5160 and 61-70. Those aged 41-50 or $>70$ were least likely to be interested, with reasons given being perceived lack of time in the case of the former, and physical health limitations in the case of the latter. 
The relationship with education was more complex. Participants with no formal schooling (50\%) showed strong interest, as did those whose highest level of education was sixth form/high school (53\%), or who had a Bachelor's degree (50\%). However, these results need to be interpreted with caution given low numbers of respondents within specific educational categories. Possible correlations between interest in renting a plot and attitudes towards nature/perceived availability of free time were also explored, but results were inconclusive. However, it is worth noting that while $47 \%$ of individuals who said they only have free time on the weekends expressed interest in renting a plot, tending to an allotment garden may be challenging if only done on weekends (Church et al., 2015). This may point to some degree of incorrect conceptualization (and perhaps romanticization) of what allotment farming entails, highlighting the need for provision of comprehensive information prior to such a scheme being embarked upon.

\subsubsection{Governmental stakeholders}

All governmental stakeholders interviewed acknowledged the potential societal and environmental benefits allotment sites could provide; however, they were also consistent in doubting that they had the required administrative capacity and resources to implement and manage such an allotment project. There was only one interviewee with prior experience in this area; in contrast to other respondents, she argued that such a scheme requires little by way of administration and resources, and that the concept may appear more daunting initially than it actually is. However, given clear resource constraints of government actors, the option of having government supporting other organizations (such as NGOs) that would plan, implement and manage sites emerged, and was generally supported by the various respondents. However, a further significant constraint emphasized by respondents related to land ownership issues, with this discussed further in Section 5 below.

\subsubsection{Organisational stakeholders}

NGO representatives expressed strong interest in allotment gardens and other green community initiatives, highlighting funding, access to land, governmental support, and public interest as the major requirements for them to be able to set up and maintain such a project. One NGO had prior experience with a small scale allotment project. This was oversubscribed when established and considered successful by the scheme managers, with plot holders exhibiting a good level of commitment; however, because the land was loaned to the NGO by a private owner, it eventually had to be returned and the scheme was discontinued. A second NGO did not have direct experience with allotments but manages a number of community garden projects, which have also been met with enthusiasm, and which are considered to be successful. Both NGOs were therefore optimistic about the prospects for uptake of such a scheme.

\subsection{Policy}

The multifaceted nature of an allotment site necessarily makes policy considerations somewhat complex, with policies potentially of relevance including those related to land acquisition and land use, agriculture, and food, as well as various social and community policies (White and Bunn, 2017). While relevant policies from these sectors were identified for Malta, this overlap of relevant policy spheres (and institutional responsibilities) is likely to pose a significant hurdle to establishing a functional framework for implementation of such projects. Indeed, countries with successful allotment projects typically have dedicated allotment policies and/or regulations. In the UK, for example, these are established through the Allotments Act (1950), with local councils empowered to manage these sites through the Localism Act (2012). Further examples can be found throughout the EU, such as Ireland's Acquisitions of Land (Allotments) Act (1926), Germany's Federal Act of Small Gardens (1983), Austria's Federal Laws on the
Regulation of Allotment Gardening (1958), and Denmark's Allotment Gardens Act (2001). The commonalities between these are that they address issues of land acquisition and the preservation of the site's designation as an allotment site, and typically establish a framework for their management - either through self-governing bodies or through local authorities and councils. As noted, Malta has no such policies at present. This gap and related implications are discussed further below.

\section{Discussion and conclusions}

This study set out to examine the feasibility of establishing community allotment gardens on abandoned agricultural land within the peri-urban environment of selected localities in Malta, applying a methodology based on place, people, and policy considerations. Abandoned agricultural land was found to be a ubiquitous feature of the local landscape and the negative impacts of this abandonment are clearly observable. Such land is not currently available for public use. Community allotment gardens were therefore envisaged as a possible means for both rehabilitating abandoned agricultural parcels, and providing opportunities for the public to engage in recreational and productive activities within a natural setting.

The results of this exploratory study are promising. The assessment of land availability indicated at least one suitable site within each of the three localities examined, meeting all relevant criteria of access, productive potential, and deliverability. In other words, these sites could be converted to allotments that are likely to have a reasonable expectation of success with relative ease. Other land parcels within the localities could also potentially be rendered suitable through some site modification works. In the course of this exercise, the extent of agricultural abandonment across the Maltese Islands also became evident, confirming observations already made in the literature (Cassar, 2010; Sultana, 2015). Given this fact, and considering that the trend of increasing agricultural abandonment persists, it is reasonable to assume that there are, or are likely to be in future, further suitable plots available across the Maltese Islands, beyond those identified in this study. However, their suitability would need to be considered on a caseby-case basis. The suitability criteria adapted for this study have been confirmed to be appropriate for application in the local context and could be used for this purpose. The strong degree of enthusiasm for and interest in allotment gardens expressed by members of the local community is also considered promising. This, together with the success of prior small-scale allotment schemes, appears to suggest that there are potential clients interested in such a scheme, and that there can be a reasonable expectation of uptake. Other interviewed stakeholders were likewise generally supportive of such an idea, at least in principle. However, key constraints relating to resource and administrative capacities were identified.

In conclusion, therefore, the key ingredients of unutilized agricultural land (place) and interested stakeholders (people) appear to be present. However, key challenges related especially to the third pillar (policy) remain. The first challenge is the present complete absence of a legal or policy framework that would allow for such use. Such a framework would need to, at a minimum: (i) establish a clear definition of allotments for the Maltese context, (ii) define areas suitable/not suitable for such land use, (iii) establish planning application/approval/ registration procedures for such land conversion, and (iv) identify entities that will hold administrative and regulatory responsibility for such sites. Furthermore, it will be critical to include provisions to ensure the longevity of such schemes and in particular, that allotments do not become merely a means to an eventual end of speculation for urban development. Key elements of such a policy framework can be adapted based on experiences elsewhere. Of relevance to the Maltese situation, for example, are policy instruments that consider the repurposing of derelict land for allotments (as can be found in Irish policy), that empower local authorities (as in UK policies), and that safeguard the longterm provision of such sites (as in many European cases reviewed). 
Related to the latter, security of tenure in the long term is also important to ensure longevity. Provisions for periodic review of any new allotment policy are also needed. Finally, it is important to consider how such a framework could be translated into concrete site-specific planning guidance. Based on our analysis, it would appear that a twotiered approach would be needed: (i) definition and elaboration of concepts and relevant planning procedures at national level, through establishment of a dedicated allotment policy; and (ii) identification and designation of suitable tracts of land at local level, possibly through Local Plans.

For successful implementation of allotment schemes on a nationwide scale, there would furthermore need to be efforts to ensure better coordination and streamlining of land ownership data. At present, such data is disparate and often ambiguous, and consequently disputes relating to delineation of land parcels are common. Such conflicts could create significant legal hurdles to implementation of allotment projects. Furthermore, the willingness of landowners/lease holders to make their land available for allotments needs to be explored in more detail, particularly when land is under private rather than governmental ownership. One incentivizing option that could be considered is the option of earning income from rental of allotment plots; regulation of such revenue-generating uses would need to be explored. If, conversely, government land is made available for such projects, procedures need to be in place to ensure that land transfers can be effected in a timely manner. These aspects are proposed as future research directions.

Furthermore, it is necessary to consider how the human and financial resource constraints identified by interviewed stakeholders can be overcome, with one option for the former being the establishment of collaborative partnerships involving governmental and non-governmental organizations. As noted, governmental organizations appear willing to provide support in principle but are concerned about their ability to contribute in practical terms, while non-governmental organizations appear willing to undertake the on-the-ground-work necessary for implementation of such a scheme, provided that government provides a facilitating and enabling framework, and the necessary support. Financial dimensions require further study; future research should address both options for funding the initial capital expenditure required, and for ensuring a stable flow of finance throughout the project lifetime for maintenance purposes.

Funding

This research did not receive any specific grant from funding agencies in the public, commercial, or not-for-profit sectors.

\section{Declarations of interest}

None.

\section{Acknowledgments}

The authors are grateful to Prof. Louis F. Cassar and Ms. Kimberly Merten for assistance during field surveys.

\section{References}

Acton, L., 2011. Allotment gardens: a reflection of history, heritage, community and self. Pap. Inst. Archaeol. 21, 46-58. https://doi.org/10.5334/pia.379.

Agnoletti, M., 2014. Rural landscape, nature conservation and culture: some notes on research trends and management approaches from a (southern) European perspective. Landsc. Urban Plan. 126, 66-73. https://doi.org/10.1016/j.landurbplan.2014. 02.012 .

Barthel, S., Isendahl, C., 2013. Urban gardens, agriculture, and water management: sources of resilience for long-term food security in cities. Ecol. Econ. 86, 224-234.

Bath and North East Somerset Council, 2015. Available:. Allotment Management Plan 2015 Accessed: 15/01/2018. https://democracy.bathnes. gov.uk/documents/ s39791/E2674z\%20BNES\%20Council\%20Allotment\%20Management \%20Plan $\% 202015 \% 20$ final.pdf.
Baycan-Levent, T., Vreeker, R., Nijkamp, P., 2009. A multi-criteria evaluation of green spaces in European cities. Eur. Urban Reg. Stud. 16 (2), 193-213.

Bell, S., 2016. Introduction. In: Bell, S., Fox-Kämper, R., Keshavarz, N., Benson, M. Caputo, S., Noori, S., Voigt, A. (Eds.), Urban Allotment Gardens in Europe. Routledge, Oxon, pp. 1-7.

Bishop, R., Purcell, E., 2013. The value of an allotment group for refugees. Br. J. Occup. Ther. 76 (6), 264-269. https://doi.org/10.4276/030802213X13706169932824.

Breuste, J.H., Artmann, M., 2014. Allotment gardens contribute to urban ecosystem service: Case study Salzburg, Austria. J. Urban Plan. Dev. 141 (3), A5014005.

Cabezas, M., Jiménez, M., Ortiz, A., Rodrigo, T., 2016. European urbanization trends. BBVA Research. Available: https://www.bbvaresearch.com/en/publicaciones/european-urbanization-trends/ Accessed: 10/10/2018.

Cassar, L.F., 2010. A Landscape Approach To Conservation: Integrating Ecological Sciences And Participatory Methods. International Environment Institute, Msida.

Church, A., Mitchell, R., Ravenscroft, N., Stapleton, L., 2015. 'Growing your own': a multi-level modelling approach to understanding personal food growing trends and motivations in Europe. Ecol. Econ. 110, 71-80.

Colding, J., Barthel, S., 2013. The potential of 'Urban green commons' in the resilience building of cities. Ecol. Econ. 86, 156-166.

DeSilvey, C., 2003. Cultivated histories in a Scottish allotment garden. Cult. Geogr. 10, 442-468.

Dwyer, J., Temple, M., Jones, J., Muscat, R., Cordina, G., Vella, S., 2014. Towards a New Agricultural Policy for Malta. Final Report to the Director of Agriculture. Malta. CCRI, Gloucester.

European Environment Agency, 2017. Landscapes in Transition: an Account of 25 Years of Land Cover Change in Europe. Publications Office of the European Union, Luxembourg.

Farrar, Ironside, 2009. Available:. Gowkthrapple Allotment Feasibility Study (Final Report for the Scottish Government) Accessed 30/11/2017. https://issuu.com/ gcvgreennetworkpartnership/docs/120815133335a1de68ec58eb40119f2283968d000fb3.

Foley, C., 2014. Of Cabbages and Kings: the History of Allotments. Frances Lincoln Limited, London.

Fuchs, R., Herold, M., Verburg, P.H., Clevers, Jan G.P.W., Eberle, J., 2015. Gross changes in reconstructions of historic land cover/use for Europe between 1900 and 2010 Glob. Chang. Biol. 21 (1), 299. https://doi.org/10.1111/gcb.12714.

Gant, R.L., Robinson, G., Fazal, S., 2011. Land-use change in the 'edgelands': policies and pressures in London's rural-urban fringe. Land use policy 28 (1), 266-279.

Gosling, E., Williams, K.J.H., 2010. Connectedness to nature, place attachment and conservation behaviour: testing connectedness theory among farmers. J. Environ. Psychol. 30 (3), 298-304. https://doi.org/10.1016/j.jenvp.2010.01.005.

Government of Malta, 2011. Available:. Cittadella Masterplan Accessed: 12/10/2018. https://mgoz.gov.mt/en/Pages/Cittadella-Masterplan.aspx.

Government of Malta, 2014. The Malta Government Gazzette. No. 19, 252. No. 473 Local Councils Act (Cap. 363). Estimated Population by Locality, $31^{\text {st }}$ March 2014.

Government of Malta, 2015. Malta - Rural Development Programme (National) 20142020. Funds and Programmes Division Within the Ministry for European Affairs and Implementation of the Electoral Manifesto.

Holmer, R.J., Clavejo, M.T., Dongus, S., Drescher, A., 2003. Allotment gardens for Philippine cities. Urban Agric. Mag. 11, 29-31.

Horsted Keynes Parish Council, 2017. Available:. Allotment Site Selection Criteria Accessed 10/12/2017. http://horstedkeynesparishcouncil.com/wp-content/ uploads/2015/01/HKNP022.pdf.

Jones, N., Fleskens, L., Stroosnijder, L., 2016. Targeting the impact of agri-environmental policy - future scenarios in two less favoured areas in Portugal. J. Environ. Manage. 181, 805-816. https://doi.org/10.1016/j.jenvman.2016.07.001.

Kabisch, N., Strohbach, M., Haase, D., Kronenberg, J., 2016. Urban green space availability in European cities. Ecol. Indic. 70, 586-596.

Keshavarz, N., Bell, S., 2016. A history of urban gardens in Europe. In: Bell, S., Fox Kämper, R., Keshavarz, N., Benson, M., Caputo, S., Noori, S., Voigt, A. (Eds.), Urban Allotment Gardens in Europe. Routledge, Oxon, pp. 8-32.

La Rosa, D., Barbarossa, L., Privitera, R., Martinico, F., 2014. Agriculture and the city: method for sustainable planning of new forms of agriculture in urban contexts. Land use policy 41, 290-303.

Lanfranco, S., Cassar, L.F., 2003. A Description of Ecological Assets in the Vicinity of the Public Solid Waste Disposal Site at Maghtab, Malta [Report]. Malta University Services, Ltd., Msida, Malta.

Langemeyer, J., Latkowska, M.J., Gómez-Baggethun, E., 2016. Ecosystem services from urban gardens. In: Bell, S., Fox-Kämper, R., Keshavarz, N., Benson, M., Caputo, S., Noori, S., Voigt, A. (Eds.), Urban Allotment Gardens in Europe. Routledge, Oxon, pp. $115-141$.

Munroe, D.K., van Berkel, D.B., Verburg, P.H., Olson, J.L., 2013. Alternative trajectories of land abandonment: causes, consequences and research challenges. Curr. Opin. Environ. Sustain. 5 (5), 471-476. https://doi.org/10.1016/j.cosust.2013.06.010.

National Statistics Office, Malta, 2016. Agriculture and Fisheries 2014. National Statistics Office., Valletta.

Novara, A., Gristina, L., Sala, G., Galati, A., Crescimanno, M., Cerdà, A., Badalamenti, E., La Mantia, T., 2017. Agricultural land abandonment in Mediterranean environment provides ecosystem services via soil carbon sequestration. Sci. Total Environ. 576, 420-429. https://doi.org/10.1016/j.scitotenv.2016.10.123.

Otto, S., Pensini, P., 2017. Nature-based environmental education of children: environmental knowledge and connectedness to nature, together, are related to ecological behaviour. Glob. Environ. Chang. Part A 47, 88-94. https://doi.org/10.1016/j. gloenvcha.2017.09.009.

Özgüner, H., Eraslan, S., Yilmaz, S., 2012. Public perception of landscape restoration along a degraded urban streamside. Land Degrad. Dev. 23 (1), 24-33. https://doi 
org/10.1002/ldr.1043.

Perez-Vazquez, A., Anderson, S., Wiltshire, R., Fraser, R., 2006. Valuing non-market benefits derived from allotments in southeast England: a contingent valuation study. Int. J. Sustain. Dev. World Ecol. 13 (2), 103-112.

Perkins, H.E., 2010. Measuring love and care for nature. J. Environ. Psychol. 30 (4), $455-$ 463.

Planning Authority, 2015. Available:. Strategic Plan for the Environment and Development Accessed 12/10/2018. https://www.pa.org.mt/en/strategic-plandetails/strategic $\% 20$ plan $\% 20$ for $\% 20$ the $\% 20$ environment $\% 20$ and $\% 20$ development

Rego, L.F.G., 2014. Urban vegetable production for sustainability: the Riortas project in the city of Rio deJaneiro, Brazil Habitat Int. 44, 510-516. https://doi-org.ejournals. um.edu.mt/10.1016/j.habitatint.2014.10.010.

Renwick, A., Jansson, T., Verburg, P.H., Revoredo-Giha, C., Britz, W., Gocht, A. Mccracken, D., 2013. Policy reform and agricultural land abandonment in the EU. Land Use Policy 30 (1), 446-457. https://doi.org/10.1016/j.landusepol.2012.04. 005.

Restall, B., Conrad, E., 2015. A literature review of connectedness to nature and its potential for environmental management. J. Environ. Manage. 159, 264-278.

Russo, P., Tomaselli, G., Pappalardo, G., 2014. Marginal periurban agricultural areas: a support method for landscape planning. Land Use Policy 41, 97-109.

Rutt, R.L., Gulsrud, N.M., 2016. Green justice in the city: a new agenda for urban green space research in Europe. Urban For. Urban Green. 19, 123-127.

Soga, M., Cox, D.T.C., Yamaura, Y., Gaston, K.J., Kurisu, K., Hanaki, K., 2017. Health benefits of urban allotment gardening: improved physical and psychological wellbeing and social integration. Int. J. Environ. Res. Public Health 14 (1), 81.

Spilková, J., Vágner, J., 2016. The loss of land devoted to allotment gardening: The context of the contrasting pressures of urban planning, public and private interests in Prague, Czechia. Land Use Policy 52, 232-239.

Sultana, D., 2015. Numerical modelling of soil erosion susceptibility in the Maltese islands using geographic information systems and the revised universal soil loss equation (RUSLE). Xjenza 3 (1), 41-50.

Terres, J.M., Nisini, L., Anguiano, E., 2013. Assessing the Risk of Farmland Abandonment in the EU. JRC Scientific and Policy Reports. Publications Office of the European
Union, Luxembourg Doi: LB-NA-25783-EN-N.

Terres, J.M., Scacchiafichi, L.N., Wania, A., Ambar, M., Anguiano, E., Buckwell, A., Coppola, A., Gocht, A., Nordström Källström, H.,Pointereau,P., Strijker, D., Visek, L., Vranken, L., Zobena, A., 2015. Farmland abandonment in Europe: identification of drivers and indicators, and development of a composite indicator of risk. Land Use Policy 49, 20-34. https://doi.org/10.1016/j.landusepol.2015.06.009.

United Nations Department of Economic and Social Affairs, Population Division, 2014 World Urbanization Prospects: The 2014 Revision, Highlights (ST/ESA/SER.A/352). Available: https://esa.un.org/unpd/wup/Publications/Files/WUP2014Highlights.pdf Accessed 15/10/2018.

Ursino, N., Romano, N., 2014. Wild forest fire regime following land abandonment in the Mediterranean region. Geophys. Res. Lett. 41 (23), 8359-8368. https://doi.org/10. 1002/2014GL061560.

Vale of Whiethorse District Council, 2017. Available:. Allotment Site Selection Criteria Accessed 30/11/2017. http://www. whitehorsedc.gov.uk/sites/default/files/Annex $\% 20 \mathrm{~F} \% 20$ Site\%20Selection\%20Criteria.pdf.

van den Berg, A.E., van Winsum-Westra, M., de Vries, S., van Dillen, S.M., 2010. Allotment gardening and health: a comparative survey among allotment gardeners and their neighbours without an allotment. Environ. Health A Glob. Access Sci. Source 9 (1), 74

van der Zanden, E., Verburg, P., Schulp, C., Verkerk, P., 2017. Trade-offs of European agricultural abandonment. Land use policy 62, 290.

Vincenti, K., Braubach, M. (Eds.), 2013. Environmental Health Inequalities in Malta. Ministry for Health, Malta Available: https://deputyprimeminister.gov.mt/en/environmental/Documents/Policy-Coordinating-Unit/env_hlt_inequalities_in_malta.pdf, Accessed 15/12/2017.

White, J.T., Bunn, C., 2017. Growing in Glasgow: innovative practices and emerging policy pathways for urban agriculture. Land Use Policy 68, 334-344. https://doi.org/ 10.1016/j.landusepol.2017.07.056.

Wood, C.J., Pretty, J., Griffin, M., 2016. A case-control study of the health and well-being benefits of allotment gardening. J. Public Health Oxf (Oxf) 38 (3), e336-e344 doi:fdv146 [pii]. 